\title{
The fifth sun, with ancient Mexican history and astronomy
}

\begin{abstract}
This paper offers a brief preliminary new interpretation of early Mexican history, embracing the absolute chronology of the Aztecs before the Spanish Conquest (1519-21). Its full text could clarify some enigmas of their calendar, with particular emphasis on the question of intercalation, by additional key dates that were recorded in both the Mexican and the Julian calendars. The previous "ages" of both the Aztecs and the Toltecs have been examined: the two lines of traditions and the corresponding intervals differ from each other, indicating different ancestral lands and/or migrations. The author (69), is a Canadian Hungarian. He is an independent amateur scholar, originally a geologist and land surveyor with diplomas. He is proposing exact dates for the last two of the five Mexican suns or ages, based on the Legend of the Suns and other records. The beginning of the Fifth Sun is anchored to the year 1011 C.E by a total solar eclipse visible from Aztlan. By the help of several Mexican codices, an unbroken chronology could be offered from the birth of the First Sun on 6 August 1240 BCE till the end of the last world age of the Toltecs when all of the ToltecChichimec population of Tollan (Tula in the Mexican state of Hidalgo) was massacred during a major eclipse of the sun by the Aztecs. It seems that the sun needed as much blood as possible, perhaps in order to keep its reddish colour and stay alive by the help of human sacrifice.

As for the former date, referring to the total eclipse of the sun, the Toltecs may have inherited it from an earlier - maybe Olmec tribe - living in that region. The name of Olmec or Ulmec nation may have referred to people making rubber, including rubber balls. Ule means rubber in Spanish. For the first time in the history of human sciences, the ancient homeland of a nation can be located by its annals and astronomical traditions. In this case the Fifth Sun places the ancestral land of the Aztecs in the Bahamas region near Florida - agreeing with some Mexican beliefs. Astronomy and radiocarbon dating place the first decades of their migration to the south of the Great Lakes. Thus, in the author's humble opinion, the Mexica crossed over to Florida from the east, then migrated to the north. They lived at Serpent Hill or Serpent Mound (Cohuatepec or Cohuatepetl) in Ohio, then migrated westwards, apparently the region of the Great Salt Lake. Finally, they migrated southwards, to Central Mexico. In a possible sequel of this paper the author, or other expert historians, could re-interpret certain Mexican codices with almost two cycles of 52 years missing or lost. The Codex Chimalpopoca seems to be the most reliable source for a correct and continuous chronology of the Mexica.
\end{abstract}

Volume 2 Issue 6 - 2018

\section{Zoltan Andrew Simon}

Geologist and land surveyor with diplomas, Canadian Hungarian amateur scholar, Canada

\begin{abstract}
Correspondence: Zoltan Andrew Simon, Geologist and land surveyor with diplomas, Canadian Hungarian amateur scholar, 72 Best Crescent, Red Deer, AB, Canada, Tel I (403) 392-9189, Email zasemon@hotmail.com
\end{abstract}

Received: September 15, 2018 | Published: December 18 2018

\section{Toltec chronology}

The Toltec Relaciones of Ixtlilxochitl (1578-1650) can be combined with the Codex Chimalpopoca that correctly placed Tula's destruction and the dispersal of the Toltecs in 1064 C.E, a year 1-Flint. Here we do not have the space to discuss the further astronomical proofs - three solar eclipses in Mexico - that could form another study about the Toltec "ages." The sequence of his ages reflects the arrangement in the Codex Vaticanus A, contradicting the Stone of the Sun. He based his work on a Toltec chronology, not on Aztec traditions.

\section{The five suns: early aztec-nahuatl eclipse records}

The Annals of Cuauhtitlan in Bierhorst ${ }^{1}$ shows the earliest candidate for the Fifth Sun, "They say the sun that exists today was born in 13 Reed [751], and it was then that light came, and it dawned. Movement Sun, which exists today, has the day sign 4 Movement, and this sun is the fifth that there is." Graulich ${ }^{2}$ confirms that the year 13Reed refers to the birth of the present sun for the Mexica, reminding us that the Fourth Sun more or less coincided with the epoch of the Toltecs. Others including Horan ${ }^{3}$ wrote of the Stone of the Sun, “... the beginning of the present world - given as 1011 A.D." According to McIvor ' “... the Aztec calendar stone, in addition to all its other layers of fascinating information, seems to be a permanent record of an independent observation of an unusual star that was recorded by the Chinese in 1011 ce..." Florescano ${ }^{5}$ claims that 1011 was the year of the birth of the Fifth Sun but he does not explain where and why. Maybe it was his intelligent guess and he was right. A possible explanation for the discrepancy of dates and versions of the Legend of the Suns between the two major groups of traditions (i.e., Toltec and Aztec) is that the "creation" of "the sun that exist today" is datable to a few centuries earlier in Central Mexico than in Aztlan (an a flooded island somewhere to the north of Mexico). Aztlan's inhabitants must have observed a newly created sun - its rebirth after a total solar eclipse - that had not been noticed in Mexico. The different versions of the "Legend of the Suns" are the consequences of the very different locations of the ancient observers. (We cannot mix apples and oranges. Talking about the ages or suns, the Aztec records cannot be mingled or combined with those of the Toltecs).

The Aztec ruler Motecuhzoma II was in Spanish captivity for several months, with the opportunity to consult a map of Cortés (later published in 1524). It shows many place-names along the Bay of Mexico, including "Florida". ${ }^{3,6} \mathrm{He}$ may have been able to match and identify the maps of his empire with those of the Spaniards. A 
16th century record of Durán ${ }^{7}$ claims that the Aztecs originated from Aztlan, an island near Florida. Maybe Durán's source was a Spaniard that had witnessed Motecuhzoma's identification of Aztlan with the region of Florida.The latest suggested year for the Fifth Sun is the year 1427 that may have been the year when the commemorative Stone of the Sun was carved. It does not refer to the eclipse of 1426 about the death of King Chimalpopoca. The "Piedra del Sol" was a monument of thanksgiving for the Fifth Sun. The year-glyph 13-Reed stands out. It may have been carved in 1479 or 1427 but the 13-Reed refers to a cataclysm on an anniversary. The date of its carving seems unimportant or irrelevant. We may assume that seven xiuhmolpillis, or 52-year bundles have passed between the birth of the Fifth Sun and the carving of this majestic commemorative stone. The "Piedra del Sol" or the "Stone of the Sun(s)" is not a calendar stone at all. Rather, it is a monument celebrating the five ages of ancient Mexican history.

Prescott ${ }^{8,9}$ wrote a captioning under one of his illustrations, "Representation of the seasons by the Aztecs, on bas-relief." See Figure 1. Maybe he has borrowed the drawing from Alexander von Humboldt's book that showed the same four scenes or ages, not "seasons." The original of the four separate drawings may have been an old and damaged version of the Codex Vaticanus 3738 on paper. Without doubt, the four drawings are identical. But Humboldt reproduced colorful drawings in his book (that one cannot find on the Internet now). It is unlikely that he has seen a bas-relief painted in vivid colours. Two millennia would have eroded most of the paint from a sculptured bas-relief. As for the Fifth Sun, "the golden mean in all things" is the best approach between the extreme suggestions, 751 and $1427 \mathrm{CE}$. A search yields no reasonable candidate for a near total solar eclipse in central Mexico in the proper year but there are excellent candidates to the north. The ancestors of the Mexicans lived in two regions simultaneously: one of the groups in central Mexico, while another group somewhere to the north. A significant geographical separation provided almost totally different key events for their "ages." Earthquakes, volcanic eruptions, floods, famine, plagues, climatic irregularities, and hurricanes would not affect faraway regions equally. The famous Stone of the Sun in Mexico City and the Coronation Stone of Motecuhzoma II (or Moctezuma II) both display these carved two glyphs (13-Reed and 4-Movement) together. They cannot be separated. Traditions add that this double event - the earthquake and the eclipse - marked the beginning of the Fifth Sun. Aztec tradition located Aztlan near Florida. ${ }^{7}$ The Spanish texts have blancura and garzas ('whiteness' and 'herons'). White herons exist only in Florida, nowhere else in North America. According to $\mathrm{Coe}^{6}$ Sahagún told a Toltec tradition allowing that their Huehue-Tlapallan (old Tlapallan) may have been the same place as the island of Aztlan. The Mayas remembered an ancient land in the east where long ago different races lived together in peace.

Having a preliminary geographic and chronological frame, one can find all the possible dates when major solar eclipses have taken place in North and Central America. We must beware of the possibility that the sequence of the five suns or ages may not have been established correctly everywhere. Their sequence in Bierhorst ${ }^{1}$ - that matches the two carved records showing the "4 Movement" sign in a year "13 Reed" - and their durations fit well as follow:

\section{i. 4-Water 676 years;}

ii. 4-Jaguar 676 years;

iii. 4-Wind 364 years;

iv. 4-Rain, ending in a year 1-Flint, for 312 years; and Water for 52 years.

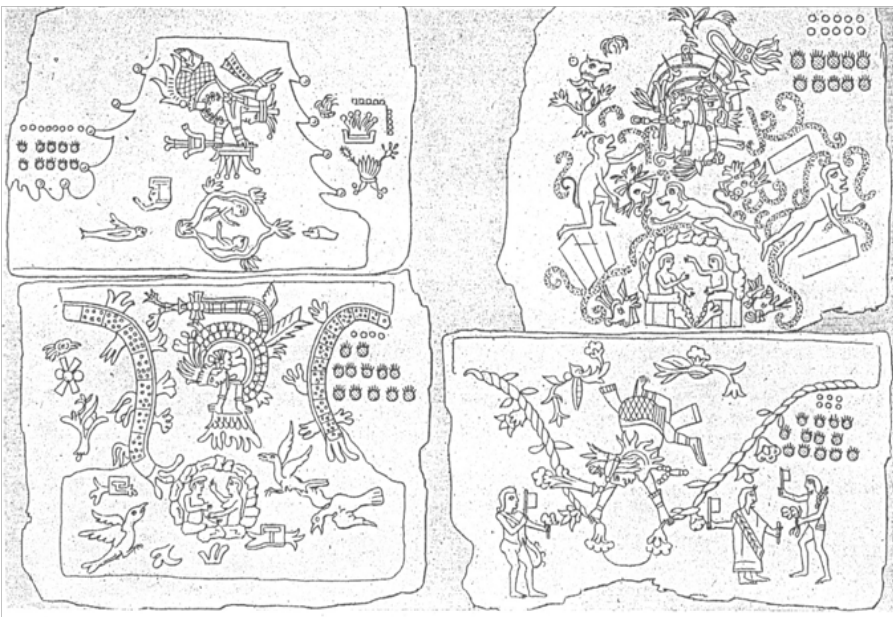

Representation of the seasons by the Aztecs, on bas-relief.

Figure I The representation of the Four Ages of the Toltecs. The second and fourth ages are shown at the bottom, ending with the solar eclipse of 30 March II3I CE when the Aztecs sacrificed the local population of Tollan, the modern Tula. A small old lady gave banners to the ones to be sacrificed. From Prescott. $^{8}$

The "312 years" is probably a rounded figure for six "bundles" or xiuhmolpillis or New Fire-binding celebrations, tying the 52 years. At the first glance, it would be logical to identify the end of the fourth age with the year 1-Flint, 1064 when the Mexica left Aztlan, as shown in the Codex Boturini (Wikipedia, Tira de le Peregrinación). See Figure 2. A search for eclipses yields a total eclipse of 12 March 750 in Aztlan near Florida, around the traditional 751 CE. At West End, Aztlan's nearest point to Florida, the eclipse was total from 17:32:24 to 17:35:19 (local time). The fourth age of the Aztecs appears to be fixed from 750 to 1064 CE, an interval of "about 312" years. This age included the inundation lasting for 52 years. The readers can check the calculation of any eclipse by WinEclipse. ${ }^{10}$ Its variable Delta-T or clock-time error is the required longitudinal shift of the eclipse paths, caused by the gradual deceleration of the Earth's rotation mainly due to tidal friction. The present author used improved Delta-T figures in his research, multiplying the values of Scsibrany by a factor of 0.98115 . The above interval ended when fiery/dirty rain fell from the sky. After a search of thirty-five years, the present author - originally geologist and land surveyor - kept seeking geological explanations for the cataclysmic events recorded by the Mexicans related to Aztlan. The main difficulty was how to anchor the beginning of the Fifth Sun. Some Mexican traditions remembered only three previous suns. This meant a possibility that the "latecomer" Aztecs must have witnessed the "creation" of a sun in Aztlan that the other earlier settlers already living in Mexico have missed because they could not see it. They tribes of the Mexica may have agreed that Aztlan (a.k.a. Tlillan-Tlapallan) had been located somewhere in the north or northeast, on an island with seven towns, sitting in a lake or rather a sea. (We could not find there a lake with an island large enough to support a large population consisting of eight tribes. For instance, the Great Salt Lake has no fish. The wildlife of its Antelope Island could not have lasted for centuries, etc.) Tlillan-Tlapallan meant the place of the red and black [ink of the scribes, symbolizing knowledge], let alone the white herons now. The search took a better turn by using the WinEclipse program. ${ }^{10}$ looking for a major solar eclipse outside Mexico in America. (The Codex Boturini does not give us a possibility that eight tribes could have arrived to North or Central America from another continent.) There was a real annular-total eclipse of the sun on April 19, 1064 
C.E. around Florida. Its magnitude at West End in Grand Bahama (26$31-43 \mathrm{~N},-78-41-48 \mathrm{~W})$ was $87.91 \%$ at $6: 18: 20$. The Aztec calendar converter of Voorburg ${ }^{11}$ shows that its year was 13 -Reed but with a day-sign 3-Dog. However, eleven days later comes a magic day, the important 1-Cipactli (Water-monster). The latter was the first day of their calendar. We will demonstrate below that it actually meant a shift of twelve days, because the Aztecs began their days at noon. Please refer to a folio in the Codex Telleriano-Remensis. ${ }^{12}$

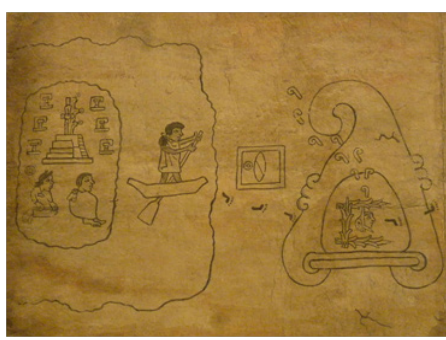

A

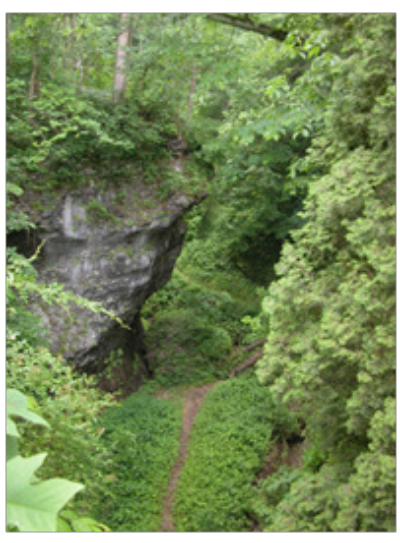

$\mathrm{C}$

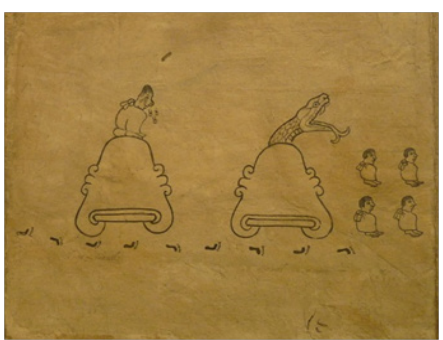

B

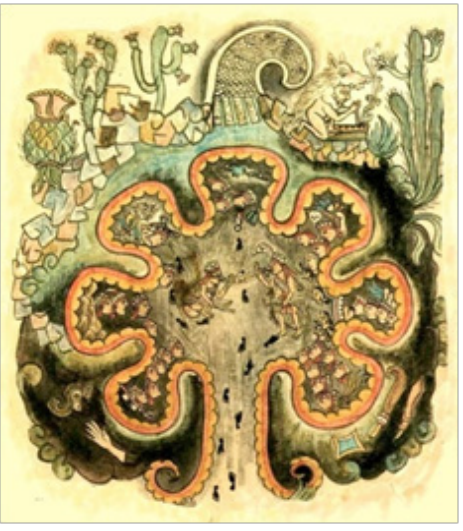

$\mathrm{D}$
Figure 2 (A) The Mexicans cross over from the flooded Grand Bahama Island to Florida in 1064 C.E; (B) These Mexicans arrive from the south to the (Great) Serpent Hill in Ohio in 1065 C.E. (The following folio shows that they lived there for 28 years, in the "Jaws of the Serpent.") From Wikipedia: Tira de la Peregrinación or Codex Boturini. (C) The overhanging, bent cliffs of old Colhuacan near (the second?); Chicomoztoc, apparently in Ohio State, near the Great Serpent Mound. From a web page that used to exist; (D) A sketchy Aztec map depicting Chicomoztoc [apparently the Seven Caves in Ohio, located near Bainbridge]. The first or "old" Colhuacan or "bent mountain" is shown near the seven caves, so it was not in Central Mexico. From Wikipedia, Chicomoztoc, originally from Historia Tolteca-Chichimeca.

About the day of the great eclipse of the sun in 1064, the Mexica began their long migration from Aztlan in the same year, a year 1-Flint. ${ }^{13}$ The native Chimalpahin's Nahuatl chronicle ${ }^{14}$ agrees on it. According to the legend, ${ }^{15}$ the southward migration began on May 24, 1064 C.E. Tezcatlipoca was already present at the end of the Fourth Sun as a helper. Like Prometheus, he advised a couple to hollow out a big cypress, and when it was the month Tozoztli [April] and the skies come falling down, get inside that boat. (The falling down of the sky may have been the result of a catastrophe predicted for April.) The text of Bierhorst in The Codex Chimalpopoca' continues, "Then Titlacahuan, Tezcatlipoca, came down and scolded them." The word "he" reveals that Titlacahuan was actually Tezcatlipoca, still alive at the "creation" of the Fifth Sun. He is a chronological anchor, a younger contemporary of Quetzalcoatl. The latter hero was old when Tezcatlipoca, "Smoked Mirror", showed him his wrinkles in a mirror. Our eclipse took place on April 19 that is consistent with the Aztec month Tozoz(ton)tli mentioned in the previous paragraph.
However, this is only one eclipse. The "Legend of the Suns" in Bierhorst $^{1}$ (1992) remembers two calamities, fifty-two years apart. After a flood the water lasted for 52 years. During the first catastrophe even the mountains disappeared within one day, because the sky fell down. But the Aztec world "tepec" or "tepetl" could mean both mountains and hills. Aztlan could have been quite a flat country if large areas of it were inundated by tectonic movements or earthquakes. We must find events important enough both for a starting point and an endpoint of a cycle that contained 52 years. The last eclipse took place on April 19, 1064 when an Aztec "god" expected a recurring cataclysm in the Mexican month corresponding to April. (Previously, the land apparently suffered a volcanic eruption, burning and sinking about the time of a total solar eclipse.) People could still see a sinking mountain or hill. The Mexican legend means that those hills sank below the sea level and became invisible. It is unlikely that experts would find sunken mountains in any North American lake. Placing those in the sea is not so unreasonable. But why did the water last for fifty-two years? Did all that water evaporate on a single day at the end of that period? Does the legend imply that those mountains rose again before the departure of the Mexica? No, it does not. The legend is silent about that. It breaks off. The best explanation is that the Aztecs said goodbye to that ancient homeland at the end of those 52 years. They had enough of the unexpected calamities, the flooded country, the missing mountains, and the disappearing suns. They must have longed for a better country where life was less complicated.

Folio 32 of the Códice Ríos has an illustration depicting the glyph "Movement" or "Earthquake" with the symbol of "night" or "star." A photograph of a Mexican statue of Tonatiuh [the Sun] depicts the glyph of 4-Earthquake (Movement) on his back, with the same glyph of the night (or star?) in the centre, and four smokes or flames on its side. See Burland and Forman, Feathered Serpent and Smoking Mirror. ${ }^{16}$ These can be indications that the Sun became so dark on a day 4-Earthquake that a star was seen, or, it became night. It probably refers to an actual earthquake, or earthquakes, too. The four flames may represent four visible solar flares. The great Stone of the Sun(s) - incorrectly called the Aztec calendar stone - and the Coronation Stone of Moctezuma II (probably $1403 \mathrm{CE}$ ) show the same five ages or suns of the Mexica, commonly called Aztecs. Of course, the Coronation Stone adds the day of Moctezuma's (Motecuhzoma II's) accession to the throne. It shows a "star" or "night" symbol in the middle of the 4-Movement glyph that is missing in the Piedra del Sol. Rather than a single star visible during a partial eclipse, it wants to express that there was a night during that day. See Figure 3. There is reliable historical information. ${ }^{17,18}$ About the $1064 \mathrm{CE}$ eruption of Sunset Crater, north of Flagstaff. It may have sent a cloud of hot ash to Florida. The Aztec tradition seems correct because a Norse saga in 1064 mentioned a similar phenomenon from around the southern cape of Greenland. A few days later the sailors met their king and reported him the terrible omen, a rain of blood. Now, if tiny particles originated from the burning forests of North America reached Greenland in large quantities, some tephra may have reached the Bahamas region, too. The deified Ce Topiltzin Quetzalcoatl flourished in the tenth century. According to the Codex Ríos $3(14 \mathrm{v})$, he prophesied that the word would be destroyed on a day 4-Earthquake. In our system he ruled from 987 to 999 then he departed from Tula. A stela of Xochicalco already shows Quetzalcoatl with a 4-Ollin (Movement or Earthquake) day symbol over his head. See Figure 4. The stela was carved in Olmec style so it could be dated before the year $1011 \mathrm{CE}$. It is possible that Quetzalcoatl was able to predict a total eclipses of the sun looming and expected to be seen on a day 4-Movement. He may have lived a few more years in Aztlan after his arrival in 999 CE there, and could 
have participated in "restoring" the solar disk to life after the eclipse of 1011 CE. The Mexicans did not know that the world was round. Otherwise, how could the culture-hero Quetzalcoatl have disappeared in the west and reappeared in the east in the person of Cortés? The Aztecs believed that the real sun was unable to go underneath the earth from the western to the eastern horizon. Then, how could a human Quetzalcoatl have performed that miraculous trick? The Mexicans have never claimed that he had circumnavigated South America. He had departed towards the east, so - luckily for the Spaniards - they expected his reappearance from the east. All evidence indicates that Aztlan was located somewhere to the northeast. We should check our anchor, the year 1064, for the beginning of the Aztec migration. The best way is to examine if there was another major eclipse of the sun near Florida 52 years earlier, in a year 13-Reed, or not.

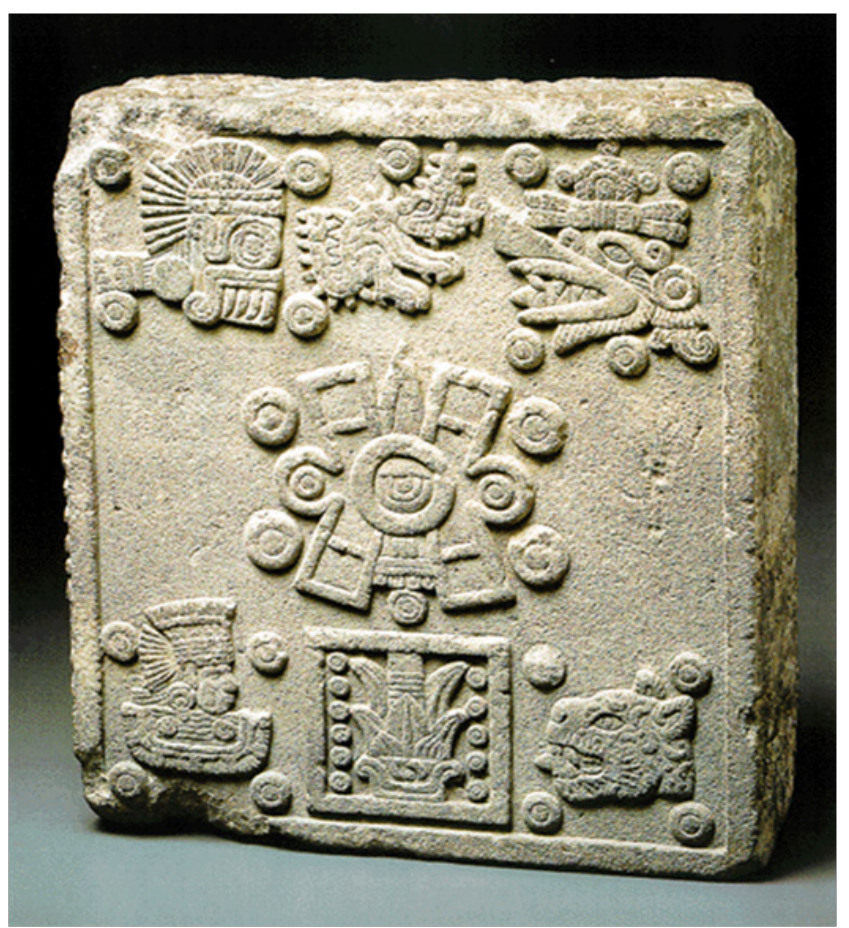

Figure 3 Coronation Stone of Motecuhzoma II showing the glyph of night inside the glyph 4-Earthquake or Movement. From http://www. latinamericanstudies.org/aztecs/moctezuma-stone.gif

To our total satisfaction, there is a perfect candidate: a total eclipse of the sun almost exactly 52 years earlier in the same region of Florida-Aztlan. It occurred in the morning of August 31, A.D. 1011, in a year 13-Reed (Acatl). The Stone of the Sun refers to this event. It was total for 4 minutes and 27 seconds at West End, ending after 11 a.m. This fits all requirements mentioned above. The mentioning of dawn at the birth of the Fifth Sun may be an ancient recollection that the last sun was born in the morning. Figure 5 shows a map with the totality zone of the eclipse and its details. Opinions are divided about the question of the ancient Mexicans' intercalations. A theory claims that they have not used any leap years or intercalation at all. Others accept the possibility of intercalary days, but have different opinions about the frequency of intercalations and the number of days inserted. León-Portilla, Los antiguos mexicanos a través de sus crónicas y cantares. ${ }^{19,20}$ cites Sahagún that once in every fourth year they applied six, not five, days of nemontemi (useless days), to correct their calendar by something similar what we call bissextile in the leap years. Sahagún believed that the extra day had coincided with the bissextile day when they pierced the ears of the infant boys and girls. Thus, although Professor Coe seems to be correct about the lack of intercalary days in the Mexican calendars after the Spanish Conquest, such intercalations may have taken place a few times before 1520 .

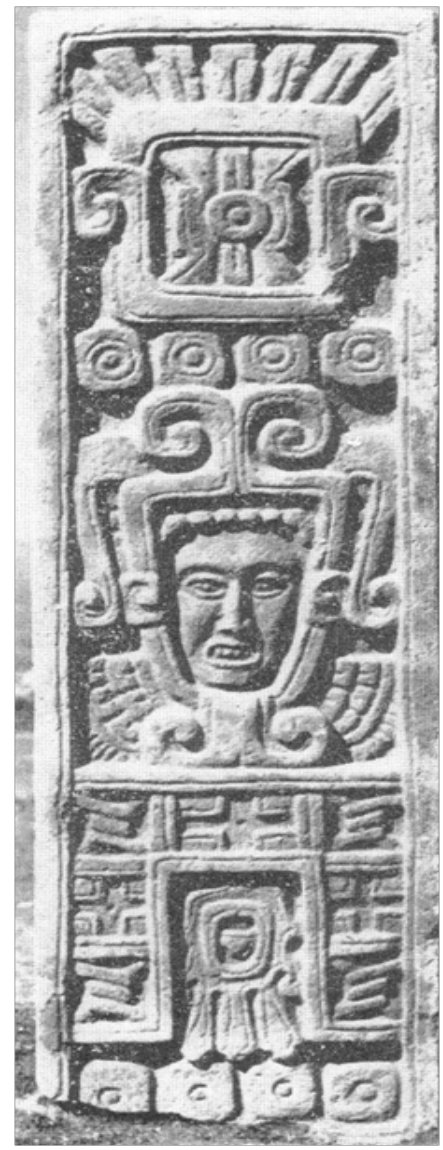

Figure $4 \mathrm{~A}$ stela of Quetzalcoatl at Xochicalco, with the glyph 4-Eathquake above his head. According to the Codex Ríos 3 (I4v), he prophesied that the word would be destroyed on a day 4-Earthquake/Movement. Quetzalcoatl was dead when the Mexica departed from Aztlan so his eclipse prediction could not have referred to a solar eclipse - the Fifth Sun - taking place after the foundation of Tenochtitlan in c. I 325 CE. ${ }^{20}$

If there were a few nameless intercalary days in our system for a few decades before the arrival of Cortés, it would mean that Caso's day-signs should be shifted back in time ("up") by several days. Also, the Aztec tradition may have attributed more importance to the terrible earthquake(s) on a certain day than dating the eclipse. Thus, the glyph 4-Movement would refer to the date of the earthquake, not the eclipse. (In our proposed system - due to the possible twelve nameless intercalary days before the spring of 1520 - an upward shift of twelve days is required for dates prior to 1476.) Major or total eclipses of the sun are often associated with earthquakes. The Mexican codices frequently mention, "In this year the sun eclipsed and an earthquake took place." The crust of our planet is sensitive. Eclipses - and even certain planetary conjunctions - often increase the tectonic pressures along fault lines and trigger earthquakes. The total eclipse of 1011 CE may have been the culprit causing the "disappearance" of some mountains or hills.

The region of the Bahamas is still gradually sinking and the sea level is rising. These do not exclude the possibility of more abrupt 
changes in the remote past. For example, the Tongue of the Ocean is clearly a rift valley of tectonic origin. It is quite impossible to date exactly its sinking. The submerged caves of the Bahamas with stalactites and stalagmites now under sea level prove that the islands once have been in much higher position, for those formations cannot grow underwater. They may have something to do with the origin of the first Chicomoztoc ("chicome+oztoc", where chicome means five plus two, or "Seven Caves") tradition. The writer saw a scientific program on the TV - probably on Discovery Channel - stating a Lucayan (Bahaman) tradition: they claimed that mankind had originated from the blue holes of the Bahamas. We highly recommend you the books of the late Rob Palmer, a diver expert. We must start thinking in Aztec calendrical terms and shall summarize our fix points that we have got so far. The tricky part is that the Aztecs began their days at noon, according to Folio $48 \mathrm{v}$ of the Codex Telleriano-Remensis. See Quiñones Keber, Codex Telleriano-Remensis: Ritual, Divination, and History in a Pictorial Aztec Manuscript. ${ }^{21}$ There is further evidence amongst some Mexican nations for a day count from midday to midday. Please refer to Caso, Los calendarios prehispánicos. ${ }^{22}$ The Aztecs thought, "The sun in its course is only a true sun in the morning; in the afternoon it becomes a false sun, a reflection of the true sun" See Graulich, ${ }^{23}$ Myths of Ancient Mexico (1997). An important detail perhaps escaped attention, causing an error of a day in Alfonso Caso's system for the years 1519-1521. Tenochtitlan's last king capitulated in the afternoon or evening of August 13,1521. We have a solid and rigid calendrical frame - that could be published one day as a separate book - in which this information does not fit in except applying the only solution: the insertion of a nameless intercalary day somewhere between November 8, 1519 and August 13, 1521. In our proposed new correlation we tentatively inserted a nameless intercalary day at the beginning (January or February) of the following years: 1476, 1480, $1484,1488,1492,1496,1500,1504,1508,1512,1516$, and 1520 , a total of 12 intercalary days. Caso, Los calendarios prehispánicos ${ }^{22}$ states that modern calculation shows a Mexican solar eclipse on "December 1o" in 1480. His Spanish text, "el día 1o. de diciembre," actually means the abbreviation of "primero" or "1st" but many readers would render it "the tenth." Probably this happened with the fist edition of the manuscript of Díaz. ${ }^{24} \mathrm{He}$ may have written "1o. de Julio" for the "Night of Sorrow" or "Noche Triste", meaning the small hours of July 1, but the editor or the printer has apparently changed his date to "July 10 " by mistake, not anticipating its serious consequences. Bierhorst, The Codex Chimalpopoca ${ }^{1}$ referred to an eclipse in the year 10-Flint (1476). In our opinion, it must have taken place in the afternoon of February 13, 1477 (JD 2260576). This indicated that the correlation was imperfect there although Caso tried to defend his system following the criticism of Boland Weitzel regarding this discrepancy. The correct Aztec chronology based on their codices Professor Vollemaere, Chimalma, first lady of the Aztecan migration of 1064. (c. 2000) accepts 1064 for the beginning of the "Mexica" migrations, as suggested by Chimalpahin, Gama, Veytia and Gallatin. One may also refer to Bancroft, The Works of Hubert Howe Bancroft: The Native Races. ${ }^{25}$ Leon y Gama, Descripcion histórica y cronológica de las dos piedras ${ }^{26}$ accepts the key date of $1064 \mathrm{CE}$ for their departure from Aztlan. Professor Johansson, La fundación de México-Tenochtitlan, ${ }^{27}$ suggests that the Mexica left Aztlan in 1168 and the city's foundation took place in 1364. Our system gives 1064 CE for their departure from Aztlan, placing Tenochtitlan's foundation between 1318 and 1325 .

Chimalpahin Cuauhtlehuanitzin's works support the year 1064 for the beginning of the migration. A paper indicates that the dates of Chimalpahin and the Codex Chimalpopoca are generally very reliable. See Therrell, Stahle, and Soto, Aztec Drought and the 'Curse of One Rabbit'. ${ }^{28}$ The Codex Chimalpopoca claims that the Mexitin (Mexica) set out from Aztlan in 1090 or in 1 Flint (1064) but "all the Colhuaque went their own way" [from Aztlan] as early as 1064 CE. In the Codex Boturini one of the eight tribes separated from the others in 1064, or shortly afterwards. Old Coatepec-Coatepetl was probably considered as part of Aztlan's region. Huitzilihuitzin I lost a battle at Chapoltepec in 1240 but his nation was victorious in 1243 . See Bierhorst, The Codex Chimalpopoca. ${ }^{1}$ The Tira de le Peregrinación (Codex Boturini) (in Wikipedia) depicted this Aztec victory with the bag full of severed ears of the Xochimilcans. A codex tells in Spanish handwriting that the Aztecs had no war for 100 years, apparently between 1247 and 1347. The description of these events with detailed arguments, or the long reign of Acamapichtli (1347-1403) would require several additional pages, if not a whole book. It involves a complicated reconstruction of the missing decades by collating the Codex Telleriano-Remensis with the Codex Vaticanus 3738.

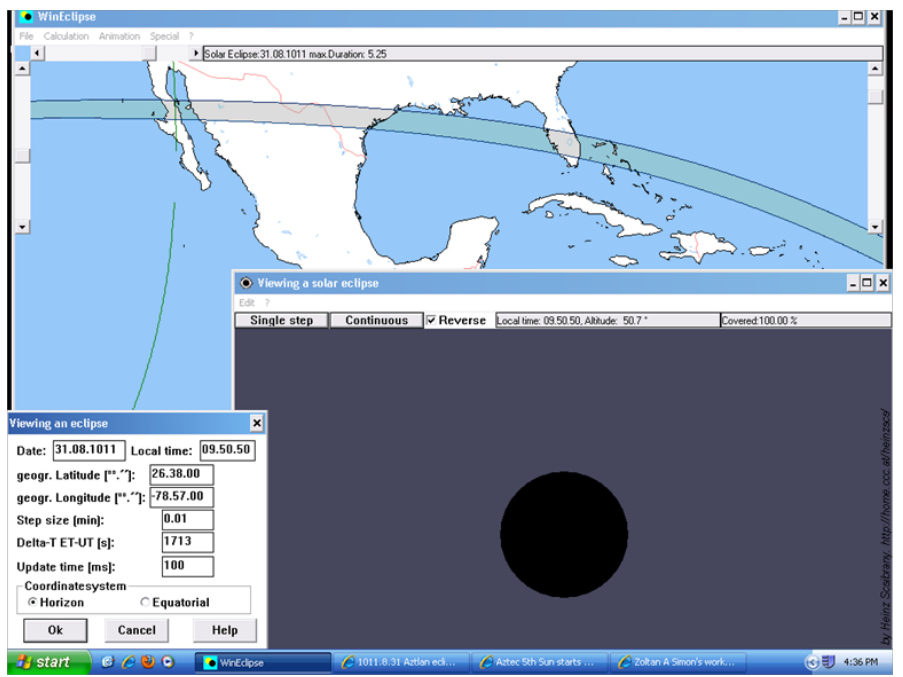

Figure $\mathbf{5}$ The birth of the Fifth Sun in Aztlan shown on the Stone of the Sun, in a year I3-Reed, on a day 4-Earthquake or Movement: 3I August IOII CE. 52 years later, around the solar eclipse of 19 April 1064 CE, the Mexica left Aztlan (the Bahamas) by canoes and landed in Florida. One of the tribes landed on a spot where the stars of the sky became visible during the eclipse.Worse, their god made a tree fall towards them. These two bad omens prohibited this eighth tribe to join the other seven tribes that ended up in Chicomoztoc, the seven caves in Ohio. (The Codex Boturini depicts that the stars became visible for this unfortunate tribe in $1064 \mathrm{CE}$, as the sky symbol above them indicates. That tribe arrived in Tollan/Tula well before the Mexica and mingled with the survivors of the Toltecs but soon were massacred by the Aztecs in II3 I CE).

The writer is of the opinion that the effigy mound called the Great Serpent Mound is a monument built for the honour of Quetzalcoatl ('Feathered Serpent'), god of the air, who reappeared in the form of Halley's Comet for his Mexica nation in 1066 CE. The appearance of the same comet is associated with the birth or youth of Huitzilopochtli as well. See Graulich, Myths of Ancient Mexico (1997: 18) and Figure 6. The Codex Telleriano-Remensis depicts several comets as celestial serpents so the two notions are identifiable. Graulich (1997: 18) shows a drawing from the Codex Azcatitlan depicting a smoking star or comet observed during three Mexican "months." Each of those months had twenty days. Thus, the ancestors of the Mexicans have apparently seen Halley's Comet for sixty days. This is comparable to the record of the fragmentary Frankish History that relates, "At the 
same time a comet appeared, for nearly three months, sending out many rays to the south..." In China, the comet was first seen in the constellation Pegasus on April 2, 1066 CE. Other observers wrote that "it shone until nearly the beginning of June" in 1066 CE.

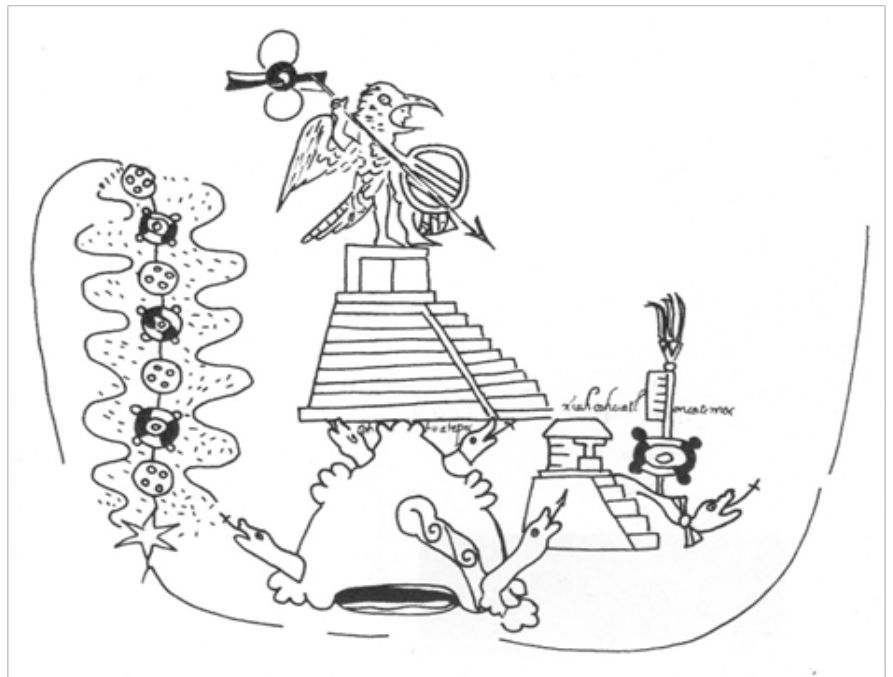

Figure 6 The young Huitzilopochtli at Cohuatepec (Great Serpent Mound). The smoking star (xiuhcoatl or "fire serpent") going down seems to record the disappearance of Halley's Comet that the Mexica have seen for sixty days. The black-and white "lifesaver" glyphs represent a 20-day month each. The four small dots in the circles between the may mean four-day festivals between the months. The banner at the word oncatemoc (?) may refer to the month Panquetzaliztli. From Graulich, Myths of Ancient Mexico, 1997: 18, taken from the Codex Azcatitlan. Although Halley's Comet "officially" appeared in April $1066 \mathrm{CE}$, it may have been seen at its reappearance during the battle near Hastings on 14 October 1066. The Bayeux Tapestry depicted Halley's Comet after King Harold's coronation, though the appearance of the comet occurred later, allegedly from 24 April to I May 1066. Both the Tapestry and the "Banner Raising" month of Codex Azcatitlan, plate 6, could be correct if the comet was visible again from October 14 to November 30 in the year 1066 CE. (The correlation of Rafael Tena places the 20-day month last from November 30 to December 19. From Wikipedia: Panquetzaliztli. Thus, another possibility is that Huitzilopochtli was born after the sighting of Halley's Comet, at the turn of November/December in 1066 CE.) We can find beautiful photographs, sculpture and illustrations under "xiuhcoatl" on the Internet.

The ancient Mexicans believed that comets were fiery snakes on the sky. Modern astronomers tell us that comets are actually called "dirty snowballs." Returning to Huitzilipochtli, we assumed that he had a chronological role to fix our dates around $1064 \mathrm{CE}$, advising a couple to get prepared for a flood. The readers may ask, "Then, how is it possible that he was born in 1066 CE when Halley's Comet appeared? (He was a child running amok around Serpent Mound while killing many people.) However, these come legends so the age of their gods is immaterial. That crazy boy may have been the reincarnation of the old Huitzilipochtli, just as Quetzalcoatl was not a single person's name. There were many Quetzalcoatls: the name meant a title or rank. For comparison, the Christians wrote in many centuries, "The Pope" and that name referred to many historical persons.

Finally, Figure 7 shows a nice sample representation of a partial eclipse of the sun from Quiñones Keber, Codex TellerianoRemensis. ${ }^{12}$ We find many of them depicted in the codex. Milbrath, Eclipse Imagery in Mexica Sculpture of Central Mexico (1995) offers you more ideas. Wikisource, The Conquest of Mexico, could be very useful for an illustrator or a movie-maker. ${ }^{29,30}$

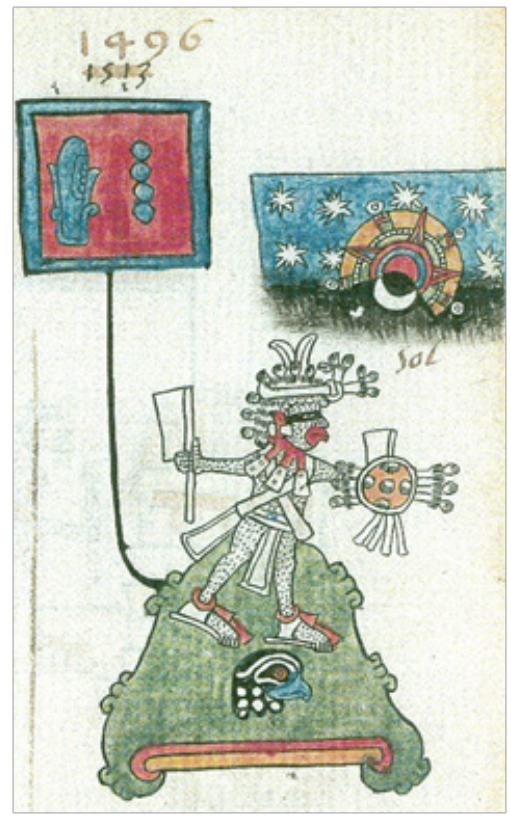

Figure 7 (A) Folio 40v of the Codex Telleriano-Remensis depicts a partial eclipse of the sun. The codex has several other representations of solar eclipses as well. The seven stars may indicate that some of the stars became visible. From Quiñones Keber.'2

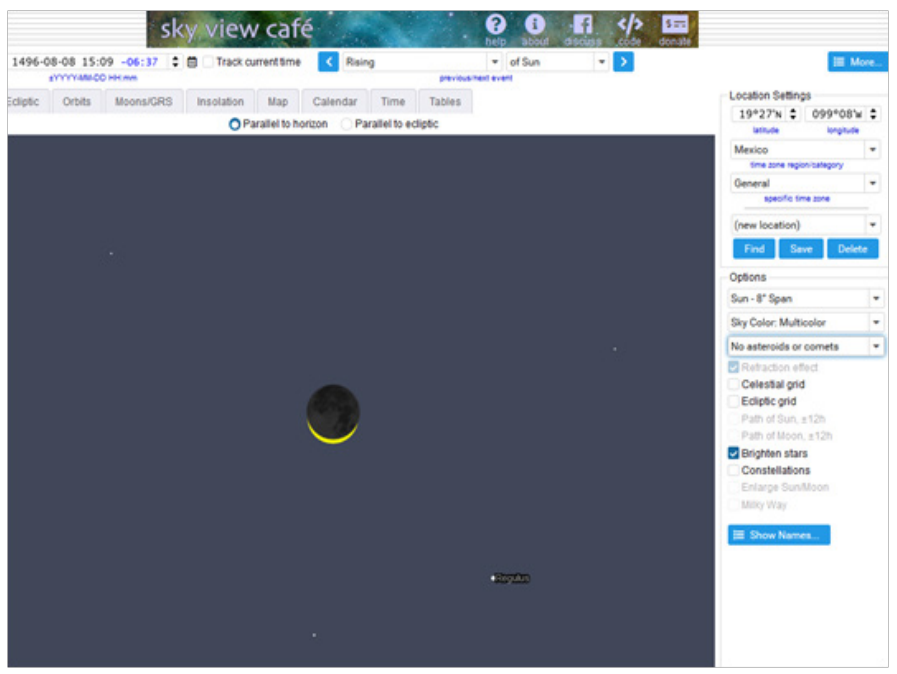

Figure 7 (B) For comparison, a modern reconstruction of the same eclipse that took place on August 8, I496 CE, using the website www.skyviewcafe. com for the location of Tenochtitlan, the modern-day Mexico City, The Sky View Café astronomy program shows the same crescent-shaped sun at the maximum phase of the eclipse as the codex (Used by the kind permission of Kerry Shetline, holder of the copyright, 2000-2008).

\section{Acknowledgment}

None.

\section{Conflicts of interest}

The author declares that there are no conflicts of interest. 


\section{References}

1. Bierhorst, John. The Codex Chimalpopoca. Tucson: University of Arizona Press, 1992.

2. Graulich, Michel. Los Reyes de Tollan. Revista Española de Antropología Americana. Madrid, Universidad Complutense. 2002;32:87-114.

3. Horan A, Thomson. Mexico, Library of the Nations series. Alexandria: VA., Time-Life Books, 1986.

4. McIvor, Robert S. Star patterns on the Aztec Calendar Stone. Journal of the Royal Astronomical Society of Canada. 2000;94(2):56-60.

5. Florescano Enrique. National narratives in Mexico: a history. Norman. University of Oklahoma Press. 2006.

6. Coe Michael D. America's First Civilization. New York: American Heritage Publishing. 1968.

7. Durán, Diego, Heyden. The history of the Indies of New Spain. Norman: University of Oklahoma Press. 1994.

8. Prescott, William Hickling. The world of the Aztecs. Barcelona, Minerva. 1974. London. John Gifford. 1979.

9. Prescott. The Conquest of Mexico Volume 1/List of Illustrations.

10. Scsibrany, Heinz. Win Eclipse. 2005.

11. Voorburg R. Aztec calendar converter. 2003.

12. Quiñones Keber E. Codex Telleriano-Remensis: Ritual, Divination, and History in a Pictorial Aztec Manuscript. Austin, University of Texas Press. 1995

13. Codex Boturini.

14. Chicomoztoc.

15. Aztlán.

16. Burland C and W Forman. Feathered Serpent and Smoking Mirror: The Gods and Cultures of Ancient Mexico. London, Orbis Publishing. 1975.
17. Lopes RMC. The Volcano Adventure Guide. Cambridge, Cambridge University Press. 2005.

18. Vollemaere, Antoon Leon. Chimalma, first lady of the Aztecan migration of 1064. 2000 .

19. León-Portilla, Miguel. Los antiguos mexicanos a través de sus crónicas y cantares. Mexico City: Fondo de Cultura Económica. 1983.

20. León-Portilla, Miguel. Quetzalcóatl. Mexico City: Fondo de Cultura Económica. 1968.

21. Milbrath S. Eclipse Imagery in Mexica Sculpture of Central Mexico. Vistas in Astronomy. 1995;39(4):479-502.

22. Caso Alfonso. Los calendarios prehispánicos. Mexico City, Universidad Nacional Autónoma de Mexico. 1967.

23. Graulich Michel. Myths of Ancient Mexico. Norman: University of Oklahoma Press. 1997.

24. Díaz del Castillo B. The Discovery and Conquest of Mexico 1517-1521. New York: Farrar, Straus and Cudahy. 1956.

25. Bancroft HH. The Works of Hubert Howe Bancroft: The Native Races San Francisco. The History Company. Publishers. 1886.

26. Leon y Gama, Antonio. Descripcion histórica y cronológica de las dos piedras. Mexico, Printed by Felipe de Zúñiga y Ontiveros, 1792.

27. Johansson K, Patrick. La fundación de México-Tenochtitlan. Consideraciones 'cronológicas'. Arqueología Mexicana, Special edition \#26, December 2007, and partly in Number 135,. Mexico City: Editorial Raíces S.A. de C.V. - INAH. 2015.

28. Therrell MD, Stahle, Soto. Aztec Drought and the 'Curse of One Rabbit'. American Meteorological Society. 2004.

29. Botley CM, White RE. Halley's Comet in 1066. Astronomical Society of the Pacific Leaflets. 1967;10(452):9-16.

30. Shetline, Kerry. Sky View Café. (C) Kerry Shetline, 2000-2008. 